\title{
ANALYSIS AND EVALUATION OF THE FUNCTIONING OF THE RESPECT INDEX
}

\author{
Hanna Sikacz, Przemyslaw Wołczek \\ Wrocław University of Economics, Wrocław, Poland \\ e-mail: hanna.sikacz@ue.wroc.pl; e-mail: przemysław.wolczek@ue.wroc.pl \\ (C) 2018 Hanna Sikacz, Przemysław Wołczek \\ This is an open access article distributed under the Creative Commons Attribution-NonCommercial-NoDerivs license \\ (http://creativecommons.org/licenses/by-nc-nd/3.0/)
}

DOI: $10.15611 / \mathrm{ms} .2018 .3 .04$

JEL Classification: E22, G11, M14

\begin{abstract}
For many years, we have seen an increasing interest in corporate social responsibility (CSR). Within this concept, Socially Responsible Investing (SRI) is developing. This includes the emergence of stock indices of companies that meet the highest environmental, social and governance (ESG) requirements. Special stakeholders, such as investors, are paying more and more attention to the composition of stock exchange indices based on socially responsible companies. The presented paper discusses the topic of responsible investing in Poland, and its main aim is to analyze and evaluate the selection process of companies in the RESPECT Index and to present the evolution that has been made since its inception. However it cannot be clearly stated that the companies included in this index are characterized by a high level of implementation of CSR strategies. Stakeholders, especially investors potentially interested in investing in companies from this index, may feel some information insecurity associated with the description of the qualification of the companies in this index. They may also have some doubts as to the use of a survey to evaluate companies from ESG data.
\end{abstract}

Keywords: RESPECT Index, CSR/SRI/ESG indices, responsible investing.

\section{Introduction}

The RESPECT Index is designed to distinguish those companies that meet the highest level of organizational governance, informational governance and investors' relations, and most of all implement a number of factors included in environmental, social and corporate governance requirements (Environmental, Social and Governance - ESG). The index, whose abbreviation RESPECT is derived from the words: Responsibility, Ecology, Sustainability, Participation, Environment, Community, Transparency, brings together companies listed on the main stock exchange of the Warsaw Stock Exchange. The RESPECT Index has been operating since 2009 and is the first index of this type in Central and Eastern Europe. Since the beginning of its existence, the index has evolved along with the changes in the tools used to select the companies that aspire to the index.

The purpose of this article is to analyse and evaluate the process of selecting companies for the RESPECT Index and to present the evolution that has been happening since its inception. The questions that the authors of this publication put forward are as follows:

- Could the selection procedure for the RESPECT Index raise any concerns among stock holders, especially for potential investors interested in investing in companies from this index?

- Does the RESPECT Index fulfil its proper role in selecting and evaluating companies for ESG data and, consequently, identifying potentially socially responsible companies?

The analysis and evaluation was based on the desk research method, which is a method based on the analysis of existing data and the literature analysis of corporate social responsibility, responsible investing, and social indices.

\section{Responsible investment and stock indices of socially responsible enterprises}

Socially Responsible Investing (SRI) was launched in the later part of the last century in the United Kingdom. 
In its initial phase responsible investing was based on religious motives and generally meant banning the investment of capital in alcohol, tobacco or arms manufacturers. The list of forbidden industries was successively enlarged. Unfortunately, at that stage of development of responsible investing, investors could get a much lower return compared to those generated by traditional investment strategies. The breakthrough for SRI happened when some leading tobacco companies lost their court cases, resulting in the need to pay multi-million dollar compensation to those who lost their health due to smoking. Firms from the tobacco industry which would like to protect themselves from the potential experience of losses started to make provisions for possible compensation. At that time society in general began to pay attention to the level of profits generated by companies and also how companies were making such profits. The question of the co-existence of enterprises in society and their impact on the environment became increasingly important [Murawski 2011].

Nowadays, socially responsible investing can be defined as investing in securities which are either selected on traditional financial criteria or based more on the social responsibility criteria [Opinia... 2009]. These days, sustainable and responsible investing, is being talked about more and more and understood as investment with consideration of ESG factors in the selection and management of investment portfolios [Bloomberg 2017, p. 3]. Socially responsible investors direct their investments to companies that practice sustainability and comply with the principles of social responsibility. Some investors avoid investing in specific industries such as tobacco, alcohol or armaments.

Socially responsible investing has been gaining in popularity since the 1990s and this trend continues today. According to The Global Sustainable Investment Alliance study, in early 2016 the entire global SRI market can be estimated at approximately USD 22.9 trillion. The European market, with an estimated value of approximately USD 12 trillion, is the largest market share (less than $53 \%$ of the total). The US market is the second largest market with a value of approximately USD 8.7 trillion (slightly over 38\%). Other investments in SRI are in Canada (USD 1.1 trillion - 4.7\%), Australia and New Zealand (USD 516 billion - 2.3\%) and Japan (USD 474 billion $-2.1 \%)$. In relative terms, responsible investment now accounts for $26 \%$ of all professionally managed assets around the world. On the largest European market, responsible investment strategies account for $53 \%$ of all professionally managed assets. So it is clear that SRI is becoming a major force in the global financial markets [Bloomberg 2017, pp. 3-9].

To support investors seeking socially responsible societies there is an index of listed responsible companies. Nowadays every stock exchange in the world has such an index. Responsible indicators are first created to define a benchmark for CSR companies, and second, to provide a real reference for investors, taking into account their investment decisions in the ESG criteria [Indeksy CSR na świecie].

Out of the 82 stock exchanges that are part of the Sustainable Stock Exchange Initiative [Deloitte 2017, p. 5]:

- 38 include ESG indicators (over 45\%),

- 18 offer ESG training (over 20\%),

- 15 contain guidelines for the ESG area (over $18 \%$ ).

The first index of socially responsible enterprises was created in 1990 and called the Domini 400 Social Index (now the FTSE KLD 400 Index). Since then, the number of SRI indexes has increased, a few of them are listed ${ }^{1}$ :

- KLD Global Sustainability Index (GSI) (2007),

- MCSI North American ESG Total Return (NNASIU) Index (2010),

- Dow Jones Sustainability North American Index (2001),

- Dow Jones Sustainability Group Index (1999),

- Jantzi Social Index (2000),

- Calvert Social Index (2000),

- ECPI Index Family (2000),

- FTSE4Good Index (2001),

- ASPI Eurozone Index (2001),

- Johannesburg Stock Exchange SRI Index (2004),

- Ethibel Sustainability Index Global (2002).

The most recognizable index of socially responsible companies in the world is the Dow Jones Sustainability Index [GlobeScan, SustainAbility 2013, p. 8]. In Central and Eastern Europe there are other such indexes, for example VONIX (the first index of socially responsible companies in this part of Europe created by the Vienna Stock Exchange in 2008), CEERIUS - CEE Responsible Investment Universe (formed on January 13, 2009 also by the Stock Exchange in Vienna) and RESPECT, which is the subject of this study².

\footnotetext{
${ }^{1}$ A more specific list of indexes and their descriptions are available in the following publications: [Lobe, Walkshäusl 2011; Krzysztofek 2013; Murawski 2013] also online: [www.sustainable-investment.org; www.odpowiedzialni.gpw.pl].

${ }^{2}$ A comparative analysis of indices RESPECT, CEERIUS, and VONIX was created i.a. by M. Bartkowiak and B. Janik [Bartkowiak, Janik 2013]. The RESPECT Index has been the subject of research by many authors i.a.: [Adamczyk 2013; Bartkowiak, Koszel 2013; Buszko 2013; Czerwińska 2012; Jedynak 2012; Krzysztofek 2014; Marcinkowska 2009; Wiśniewski 2010; Wróblewska 2015; Zasępa 2013].
} 
Table 1. Selected issues of the ESG taken into account at the stage of defining the composition of selected indexes of shares of socially responsible companies

\begin{tabular}{|c|c|c|c|c|c|}
\hline Dimension & Issues & $\begin{array}{c}\text { Dow Jones } \\
\text { Sustainability } \\
\text { Indexes }\end{array}$ & $\begin{array}{l}\text { FTSE4Good } \\
\text { Index }\end{array}$ & $\begin{array}{c}\text { SRI Index - } \\
\text { Johannesburg } \\
\text { Stock Exchange }\end{array}$ & $\begin{array}{l}\text { RESPECT } \\
\text { Index }\end{array}$ \\
\hline \multirow{8}{*}{ Management } & corporate governance & $\mathrm{x}$ & $\mathrm{x}$ & $\mathrm{x}$ & \\
\hline & code of ethics/conduct & $\mathrm{x}$ & & $\mathrm{x}$ & $\mathrm{x}$ \\
\hline & risk management & $\mathrm{x}$ & $\mathrm{x}$ & $\mathrm{x}$ & $\mathrm{x}$ \\
\hline & Supply chain & $\mathrm{x}$ & $\mathrm{x}$ & & $\mathrm{x}$ \\
\hline & anti-corruption risk of fraud & $\mathrm{x}$ & $\mathrm{x}$ & & $\mathrm{x}$ \\
\hline & tax strategy & $\mathrm{x}$ & $\mathrm{x}$ & & \\
\hline & customer relationship management & $\mathrm{x}$ & & & $\mathrm{x}$ \\
\hline & brand management & $\mathrm{x}$ & & & \\
\hline \multirow{4}{*}{ Environmental } & policy/environmental management & $\mathrm{x}$ & $\mathrm{x}$ & $\mathrm{x}$ & $\mathrm{x}$ \\
\hline & environmental reporting & $\mathrm{x}$ & $\mathrm{x}$ & $\mathrm{x}$ & \\
\hline & climate change/management & $\mathrm{x}$ & $\mathrm{x}$ & $\mathrm{x}$ & $\mathrm{x}$ \\
\hline & eco-operational efficiency & $\mathrm{x}$ & & & \\
\hline \multirow{9}{*}{ Social } & training and development & $\mathrm{x}$ & & $\mathrm{x}$ & $\mathrm{x}$ \\
\hline & relations with employees & & & $\mathrm{x}$ & \\
\hline & equal opportunities & & & $\mathrm{x}$ & $\mathrm{x}$ \\
\hline & work standards & $\mathrm{x}$ & $\mathrm{x}$ & $\mathrm{x}$ & \\
\hline & Health and Safety & $\mathrm{x}$ & $\mathrm{x}$ & $\mathrm{x}$ & $\mathrm{x}$ \\
\hline & human rights & $\mathrm{x}$ & $\mathrm{x}$ & & \\
\hline & relations with the community & & $\mathrm{x}$ & $\mathrm{x}$ & \\
\hline & engaging stakeholders & $\mathrm{x}$ & & $\mathrm{x}$ & $\mathrm{x}$ \\
\hline & corporate governance & & $\mathrm{x}$ & & $\mathrm{x}$ \\
\hline
\end{tabular}

Source: [Deloitte 2017, p. 6].

The selection of companies for these indexes takes ESG issues into account. The results of some studies indicate a varied approach to the qualification of companies for these indices, also pointing to the significant lack of standardization within ESG evaluation of companies [Escrig-Olmedo et al. 2010, p. 442]. Table 1 presents a compilation of selected ESG issues considered at the stage of defining the composition of selected stock indexes of socially responsible companies to selected global indexes in compare to the RESPECT Index.

In the case of the Dow Jones Sustainability Indexes, 17 of the 21 listed issues are taken into account. The analysis for the FTSE4Good Index and the SRI Index - Johannesburg Stock Exchange takes into account 13 issues, while the RESPECT Index just 12 issues. Against the background of global indexes, the choice of companies on the Polish market is very limited. The analysis of the statement indicates that all indexes use a selection process of companies which implement such issues as risk management, policy/ environmental management, climate change/management, and occupational health and safety. However, some individual cases also assess: brand management, eco-efficiency, and employee relations.

\section{The functionality of the RESPECT Index}

\subsection{Analysis and evaluation of the selection process of companies}

The selection process of RESPECT companies takes place in three stages. The first step is to define a list of companies that, at the time of updating the index composition, is characterized by the highest level of stocks liquidity. At the next stage, the admitted companies are subjected to a review aimed at evaluating practices applied by companies in the area of corporate governance (compliance with the WSE Code of Best Practice), information governance and investor relations. The rating is made by the WSE in Warsaw in cooperation with the Association of Stock Exchange Issuers. It is based on publicly available reports and information published by companies on their website [Deloitte2016]. In the third stage the 
Table 2. Basic characteristics of surveys of individual editions of the RESPECT Index

\begin{tabular}{|c|c|c|c|c|}
\hline Issued & $\begin{array}{c}\text { Number of pages } \\
\text { in survey }\end{array}$ & $\begin{array}{l}\text { Number of questions } \\
\text { in survey* }\end{array}$ & Survey tape & $\begin{array}{c}\text { Structure of the survey } \\
\text { with the number of questions in a given area* }\end{array}$ \\
\hline I (2009) & 17 & $58(79)$ & $\begin{array}{l}\text { I survey } \\
\text { tape }\end{array}$ & $\begin{array}{l}\text { Strategy and corporate management }-22(30) \text { : } \\
\text { - CSR policy }-4(6) \\
\text { - functioning on the stock exchange }-18(24) \\
\text { Economic factors }-12(13) \text { : } \\
\text { - punctuality of financial liabilities - } 4 \\
\text { - profits - } 1 \\
\text { - remuneration and support for social activities - } 7 \text { (8) } \\
\text { Environmental factors- } 24(37) \text { : } \\
\text { - environmental management }-2(4) \\
\text { - materials and raw materials }-1 \\
\text { - energy and water }-2 \\
\text { - waste }-1 \text { (2) } \\
\text { - penalty - } 10 \text { (16) } \\
\text { - market and customers }-8(12)\end{array}$ \\
\hline II (2010) & 13 & $35(55)$ & & $\begin{array}{l}\text { Strategy and corporate management }-10(17) \text { : } \\
\text { - CSR policy }-4(6) \\
\text { - functioning on the stock exchange }-6(11) \\
\text { Environmental factors }-25(38) \text { : } \\
\text { - environmental management }-3(5) \\
\text { - materials and raw materials }-1 \\
\text { - energy and water - } 2 \\
\text { - waste - } 2(3) \\
\text { - employees }-9(15) \\
\text { - market and customers }-8(12)\end{array}$ \\
\hline III (2011) & 14 & $35(55)$ & $\begin{array}{l}\text { II survey } \\
\text { tape }\end{array}$ & $\begin{array}{l}\text { strategy and corporate management - } 10(17) \text { : } \\
\text { - CSR policy }-4(6) \\
\text { - functioning on the stock exchange }-1 \\
\text { Environmental factors }-25(38) \text { : } \\
\text { - environmental management - } 3(5) \\
\text { - materials and raw materials - } 1 \\
\text { - energy and water - } 2 \\
\text { - waste }-1(2) \\
\text { - penalty }-1 \\
\text { - employees }-9(15) \\
\text { - market and customers }-8(12) \\
\end{array}$ \\
\hline IV (2011) & 15 & $35(55)$ & & as above \\
\hline V (2012) & 16 & $35(58)$ & & 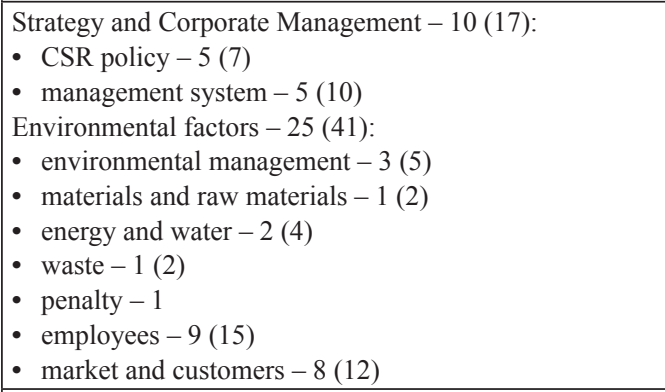 \\
\hline VI (2012) & 16 & 35 & & as above \\
\hline VII (2013) & 22 & $48(50)$ & \multirow{5}{*}{$\begin{array}{l}\text { III survey } \\
\text { tape }\end{array}$} & $\begin{array}{l}\text { Environmental - } 14 \\
\text { Social - 18(20) } \\
\text { Governance }-16\end{array}$ \\
\hline VIII (2014) & 24 & $49(53)$ & & $\begin{array}{l}\text { Environmental - } 14 \\
\text { Social }-19(23) \\
\text { Governance }-16\end{array}$ \\
\hline IX (2015) & 25 & $51(55)$ & & $\begin{array}{l}\text { Environmental - } 14 \\
\text { Social - 20(24) } \\
\text { Governance }-17\end{array}$ \\
\hline $\mathrm{X}(2016)$ & 34 & $51(55)$ & & as above \\
\hline XI (2017) & 38 & $51(53)$ & & $\begin{array}{l}\text { Environmental - } 14 \\
\text { Social - 20(22) } \\
\text { Governance }-17\end{array}$ \\
\hline
\end{tabular}

* The number in brackets includes extended questions, with additional questions.

Source: own elaboration. 
company wishing to join the RESPECT Index must answer questions included in the survey related to various features of the company's operations. Nevertheless this phase is only for those companies that have successfully completed the first two aspects of the assessment. The questionnaire contains questions dedicated to all companies or only to companies operating a particular type of activity, divided into industry, finance and services. The surveys' characteristics of the 11th edition of the RESPECT Index are presented in Table 2.

An important matter related to the surveys' analysis is indicating two major changes in the survey structure that took place in the second edition of the index (2010) and the 7th edition (2013). Therefore since the first publication of the RESPECT Index, we may talk about three types of questionnaires that are identified due to the differences in their structure.

The first type of survey represents the survey exclusively for the first edition of the index (2009). At that time it was divided into three areas: strategy and corporate management, economic and environmental factors. Another type of questionnaire for the next five editions of the index during 2010-2012 ${ }^{3}$ covers two areas: strategy and corporate governance, and also environmental factors. As can be seen, compared to the first version of the questionnaire, economic factors have been excluded. The third type of survey has been in place since 2013, since the 7th edition of the index. The fundamental change involves dividing questions into three areas, as defined by ESG, i.e. environmental, social and governance factors.

The most up-to-date version of the survey currently consists of 51 questions, two of which are from the field of social factors and are more developed, which in total gives 53 questions. The number of social questions is also the highest. It should be noted that this area has evolved from environmental factors that included elements of social factors in surveys I and II (but it is an unusual questionnaire in which questions about employees, markets and customers are located in the environmental area).

The extent of the changes in the survey can be seen in the number of pages between the first edition and11th edition which more than doubled from 17 to 38 pages. The increase in the number of questionnaire pages may be a consequence of the changed graphic design of the survey and the adapted questions to the currently observed trends in corporate social responsibility.
When assessing in brief the individual stages of the selection of companies for the index and detailed analysis of the questionnaire, some doubts should be raised with regard to:

- The omission of economic factors in the assessment of companies; only in the first edition of the index were these factors taken into account in the survey. The exclusion of economic factors from the questionnaire is of course justified due to the access to audited financial statements, but at no stage is the comprehensive assessment of the financial situation taken into account (according to the available descriptions of the stages of qualification into the index);

- A significant and serviceable part of non-financial (CSR type and others) or integrated reports, is to assess a company in the context of ESG data, because for several years since publishing the above mentioned reports, many companies have delivered a specially prepared survey which is needed to be selected for the RESPECT Index. The use of this survey may indicate an inability in the use of non-financial information reports to evaluate ESG areas in the selection process of RESPECT companies.

- The transparency of the results of the selection process of companies into the index - only the final edition of the index is issued to the public. The authors of this article failed to find out how the individual companies were evaluated in the analysed areas. It is therefore impossible to answer the question whether companies are making progress in the ESG field (those companies that are included in the minimum of two consecutive editions of the index).

- From entities that are qualified for the RESPECT Index, only those that are dominant in the capital group are evaluated. Currently it is significant that all of the RESPECT Index companies become capital groups. Altogether with the lack of information of results of the questionnaires, we can only assume that a large part of the entities passed the survey only in the dominate unit, which in the case of such a specific structure as a capital group would be a major drawback in evaluating non-financial information.

\subsection{Analysis and evaluation of index composition}

For the ten editions of the RESPECT Index 41, companies have been indexed (Table 3).

\footnotetext{
${ }^{3}$ Between 2011 and 2012 there were two editions each year. The update of index composition is assumed once a year. In particularly justified cases, ad hoc extraordinary changes are expected to occur in these two years.
} 
Table 3. Companies participating in individual RESPECT Index editions

\begin{tabular}{|c|c|c|c|c|c|c|c|c|c|c|c|}
\hline \multirow[b]{2}{*}{ No. } & \multirow[b]{2}{*}{ Company } & \multicolumn{10}{|c|}{ Year of index composition (index edition number) } \\
\hline & & $\begin{array}{l}2009 \\
(\mathrm{I})\end{array}$ & $\begin{array}{c}2011 \\
(\mathrm{II})\end{array}$ & $\begin{array}{r}2011 \\
\text { (III) }\end{array}$ & $\begin{array}{r}2012 \\
(I V)\end{array}$ & $\begin{array}{c}2012 \\
(V)\end{array}$ & $\begin{array}{r}2013 \\
(\mathrm{VI})\end{array}$ & $\begin{array}{l}2013 \\
(\mathrm{VII})\end{array}$ & $\begin{array}{c}2014 \\
\text { (VIII) }\end{array}$ & $\begin{array}{r}2015 \\
(\mathrm{IX})\end{array}$ & $\begin{array}{c}2016 \\
(\mathrm{X})\end{array}$ \\
\hline 1 & Apator S.A. & $\mathrm{x}$ & & $\mathrm{x}$ & $\mathrm{x}$ & $\mathrm{x}$ & $\mathrm{x}$ & $\mathrm{x}$ & $\mathrm{x}$ & $\mathrm{x}$ & $\mathrm{x}$ \\
\hline 2 & Bank BPH & $\mathrm{x}$ & & & $\mathrm{x}$ & $\mathrm{x}$ & $\mathrm{x}$ & $\mathrm{x}$ & $\mathrm{x}$ & $\mathrm{x}$ & \\
\hline 3 & Bank Handlowy w Warszawie S.A. & $\mathrm{x}$ & $\mathrm{x}$ & $\mathrm{x}$ & $\mathrm{x}$ & $\mathrm{x}$ & $\mathrm{x}$ & $\mathrm{x}$ & $\mathrm{x}$ & $\mathrm{x}$ & $\mathrm{x}$ \\
\hline 4 & Bank Millennium S.A. & & $\mathrm{x}$ & $\mathrm{x}$ & $\mathrm{x}$ & $\mathrm{x}$ & $\mathrm{x}$ & $\mathrm{x}$ & $\mathrm{x}$ & $\mathrm{x}$ & $\mathrm{x}$ \\
\hline 5 & Bank Ochrony Środowiska S.A. & & & & & & & & & $\mathrm{x}$ & \\
\hline 6 & Bank Pekao S.A. & & & & & & & & & & $\mathrm{x}$ \\
\hline 7 & Bank Zachodni WBK S.A. & & $\mathrm{x}$ & & & & & $\mathrm{x}$ & $\mathrm{x}$ & $\mathrm{x}$ & $\mathrm{x}$ \\
\hline 8 & Barlinek S.A. $^{\mathrm{d}}$ & $\mathrm{x}$ & $\mathrm{x}$ & $\mathrm{x}$ & & & & & & & \\
\hline 9 & 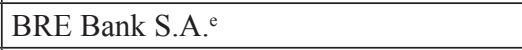 & & $\mathrm{x}$ & $\mathrm{x}$ & & & & & & & \\
\hline 10 & Budimex S.A. & & $\mathrm{x}$ & $\mathrm{x}$ & $\mathrm{x}$ & $\mathrm{x}$ & $\mathrm{x}$ & $\mathrm{x}$ & $\mathrm{x}$ & $\mathrm{x}$ & $\mathrm{x}$ \\
\hline 11 & Ciech S.A. & $\mathrm{x}$ & & & $\mathrm{x}$ & & & & & & \\
\hline 12 & DM IDM S.A. ${ }^{\mathrm{f}}$ & & & $\mathrm{x}$ & $\mathrm{x}$ & & & & & & \\
\hline 13 & Elektrobudowa S.A. & $\mathrm{x}$ & $\mathrm{x}$ & $\mathrm{x}$ & $\mathrm{x}$ & $\mathrm{x}$ & $\mathrm{x}$ & $\mathrm{x}$ & $\mathrm{x}$ & $\mathrm{x}$ & $\mathrm{x}$ \\
\hline 14 & Energa S.A. & & & & & & & & $\mathrm{x}$ & $\mathrm{x}$ & $\mathrm{x}$ \\
\hline 15 & Fabryka Farb i Lakierów Śnieżka S.A. & & & $\mathrm{x}$ & & & & & & & \\
\hline 16 & Fabryki Mebli „FORTE” S.A. & & & & & & & & & & $\mathrm{x}$ \\
\hline 17 & GPW S.A. & & & & & & & $\mathrm{x}$ & $\mathrm{x}$ & $\mathrm{x}$ & $\mathrm{x}$ \\
\hline 18 & Grupa Azoty S.A. & $\mathrm{x}^{\mathrm{b}}$ & $\mathrm{x}^{\mathrm{b}}$ & $\mathrm{x}^{\mathrm{b}}$ & $\mathrm{x}^{\mathrm{b}}$ & $\mathrm{x}^{\mathrm{b}}$ & $\mathrm{x}^{\mathrm{b}}$ & $\mathrm{x}$ & $\mathrm{x}$ & $\mathrm{x}$ & $\mathrm{x}$ \\
\hline 19 & Grupa LOTOS S.A. & $\mathrm{x}$ & $\mathrm{x}$ & $\mathrm{x}$ & $\mathrm{x}$ & $\mathrm{x}$ & $\mathrm{x}$ & $\mathrm{x}$ & $\mathrm{x}$ & $\mathrm{x}$ & $\mathrm{x}$ \\
\hline 20 & Grupa Żywiec S.A. & $\mathrm{x}$ & & & & & & & & & \\
\hline 21 & ING Bank Śląski S.A. & $\mathrm{x}$ & $\mathrm{x}$ & $\mathrm{x}$ & $\mathrm{x}$ & $\mathrm{x}$ & $\mathrm{x}$ & $\mathrm{x}$ & $\mathrm{x}$ & $\mathrm{x}$ & $\mathrm{x}$ \\
\hline 22 & Jastrzębska Spółka Węglowa S.A. & & & & & $\mathrm{x}$ & $\mathrm{x}$ & $\mathrm{x}$ & $\mathrm{x}$ & & \\
\hline 23 & KGHM Polska Miedź S.A. & $\mathrm{x}$ & $\mathrm{x}$ & $\mathrm{x}$ & $\mathrm{x}$ & $\mathrm{x}$ & $\mathrm{x}$ & $\mathrm{x}$ & $\mathrm{x}$ & $\mathrm{x}$ & $\mathrm{x}$ \\
\hline 24 & Kredyt Bank S.A. $^{\mathrm{c}}$ & & & $\mathrm{x}$ & $\mathrm{x}$ & $\mathrm{x}$ & & & & & \\
\hline 25 & Lubelski Węgiel Bogdanka S.A. & & $\mathrm{x}$ & $\mathrm{x}$ & $\mathrm{x}$ & $\mathrm{x}$ & $\mathrm{x}$ & & $\mathrm{x}$ & $\mathrm{x}$ & $\mathrm{x}$ \\
\hline 26 & Mondi Świecie S.A.g & $\mathrm{x}$ & $\mathrm{x}$ & $\mathrm{x}$ & $\mathrm{x}$ & & & & & & \\
\hline 27 & Netia S.A. & & & $\mathrm{x}$ & $\mathrm{x}$ & $\mathrm{x}$ & $\mathrm{x}$ & $\mathrm{x}$ & & & \\
\hline 28 & Orange Polska S.A. & $\mathrm{x}^{\mathrm{a}}$ & $\mathrm{x}^{\mathrm{a}}$ & $\mathrm{x}^{\mathrm{a}}$ & $\mathrm{x}^{\mathrm{a}}$ & $\mathrm{x}^{\mathrm{a}}$ & $\mathrm{x}^{\mathrm{a}}$ & $\mathrm{x}^{\mathrm{a}}$ & $\mathrm{x}$ & $\mathrm{x}$ & $\mathrm{x}$ \\
\hline 29 & PCC Rokita S.A. & & & & & & & & & & $\mathrm{x}$ \\
\hline 30 & Pelion S.A. ${ }^{i}$ & & & & & & $\mathrm{x}$ & $\mathrm{x}$ & $\mathrm{x}$ & $\mathrm{x}$ & $\mathrm{x}$ \\
\hline 31 & PBG S.A. ${ }^{\mathrm{h}}$ & & & $\mathrm{x}$ & $\mathrm{x}$ & & & & & & \\
\hline 32 & PGE S.A. & & & $\mathrm{x}$ & $\mathrm{x}$ & $\mathrm{x}$ & $\mathrm{x}$ & $\mathrm{x}$ & $\mathrm{x}$ & $\mathrm{x}$ & $\mathrm{x}$ \\
\hline 33 & PGNIG S.A. & $\mathrm{x}$ & $\mathrm{x}$ & $\mathrm{x}$ & $\mathrm{x}$ & $\mathrm{x}$ & $\mathrm{x}$ & $\mathrm{x}$ & $\mathrm{x}$ & $\mathrm{x}$ & $\mathrm{x}$ \\
\hline 34 & PKN Orlen S.A. & $\mathrm{x}$ & $\mathrm{x}$ & $\mathrm{x}$ & $\mathrm{x}$ & $\mathrm{x}$ & $\mathrm{x}$ & $\mathrm{x}$ & $\mathrm{x}$ & $\mathrm{x}$ & $\mathrm{x}$ \\
\hline 35 & PZU S.A & & & & $\mathrm{x}$ & $\mathrm{x}$ & $\mathrm{x}$ & $\mathrm{x}$ & $\mathrm{x}$ & $\mathrm{x}$ & $\mathrm{x}$ \\
\hline 36 & RAFAKO S.A. & & & & & & & $\mathrm{x}$ & & & \\
\hline 37 & RAWLPLUG S.A. & & & & & & & & $\mathrm{x}$ & & \\
\hline 38 & Tauron PE S.A. & & & & & & & $\mathrm{x}$ & $\mathrm{x}$ & $\mathrm{x}$ & $\mathrm{x}$ \\
\hline 39 & Trakcja PRKiI S.A. & & & & & & & & & & $\mathrm{x}$ \\
\hline 40 & Zakłady Magnezytowe Ropczyce S.A. & $\mathrm{x}$ & & & & & & & & & \\
\hline 41 & $\begin{array}{l}\text { Zespół Elektrociepłowni Wrocławskich } \\
\text { Kogeneracja S.A. }\end{array}$ & & & & $\mathrm{x}$ & $\mathrm{x}$ & $\mathrm{x}$ & $\mathrm{x}$ & $\mathrm{x}$ & $\mathrm{x}$ & $\mathrm{x}$ \\
\hline \multicolumn{2}{|r|}{ Number of companies in the index } & 16 & 16 & 22 & 23 & 20 & 20 & 23 & 24 & 23 & 25 \\
\hline
\end{tabular}

a - Telekomunikacja Polska S.A.; b - Zakłady Azotowe w Tarnowie - Mościcach S.A.; c - in 2013 Kredyt Bank S.A. was excluded from trading after merging with Bank Zachodni WBK S.A.; d - in 2014 the shares of Barlinek S.A. were withdrawn from the WSE; e - in 2013 mBank brand replaced the BRE Bank brand (rebranding); f - since 2014 DM IDM S.A. has been in systemic bankruptcy; $g$ - the shares of Mondi Świecie S.A. were excluded from the stock exchange trading on 7 August 2012 in accordance with the decision of the WSE Management Board; $\mathrm{h}$ - from June 2012 to July 2016 the company PBG S.A. was in systemic bankruptcy and trading of shares of Pelion S.A. The decision of the Management Board of the WSE was suspended on 8 June 2017.

Source: own elaboration. 
Table 4. The market value of RESPECT share packages - as at August 16, 2017

\begin{tabular}{|c|c|c|c|}
\hline Company & Shares Package & $\begin{array}{l}\text { The market value } \\
\text { of package (PLN) }\end{array}$ & Part of portfolio (\%) \\
\hline KGHM Polska Miedź S.A. & 103972000 & 12788556000 & 10.964 \\
\hline PZU S.A. & 247910000 & 11341882500 & 9.724 \\
\hline PKN Orlen S.A. & 103531000 & 11155465250 & 9.564 \\
\hline PGE S.A. & 796776000 & 11107057440 & 9.523 \\
\hline Bank Zachodni WBK S.A. & 30353000 & 10669079500 & 9.147 \\
\hline PGNIG S.A. & 1624608000 & 10592444160 & 9.081 \\
\hline Bank Pekao S.A. & 79636000 & 10185444400 & 8.732 \\
\hline ING Bank Śląski S.A. & 32525000 & 6371647500 & 5.463 \\
\hline Grupa LOTOS S.A. & 86543000 & 4292532800 & 3.680 \\
\hline Bank Millennium S.A. & 605345000 & 4225308100 & 3.623 \\
\hline Tauron PE S.A. & 1043590000 & 3871718900 & 3.319 \\
\hline Orange Polska S.A. & 647357000 & 3638146340 & 3.119 \\
\hline Grupa Azoty S.A. & 41439000 & 2838571500 & 2.434 \\
\hline Budimex S.A. & 11451000 & 2713314450 & 2.326 \\
\hline Energa S.A. & 200740000 & 2645753200 & 2.268 \\
\hline Bank Handlowy w Warszawie S.A. & 32664000 & 2254142640 & 1.933 \\
\hline GPW S.A. & 27192000 & 1229350320 & 1.054 \\
\hline Fabryki Mebli „FORTE” S.A. & 16137000 & 1142983710 & 0.980 \\
\hline Lubelski Węgiel Bogdanka S.A. & 11564000 & 856892400 & 0.735 \\
\hline Apator S.A. & 25505000 & 792440350 & 0.679 \\
\hline $\begin{array}{l}\text { Zespół Elektrociepłowni Wrocławskich } \\
\text { Kogeneracja S.A. }\end{array}$ & 7449000 & 666536520 & 0.571 \\
\hline Elektrobudowa S.A. & 4747000 & 529290500 & 0.454 \\
\hline Trakcja PRKiI S.A. & 35556000 & 448361160 & 0.384 \\
\hline PCC Rokita S.A. & 3144000 & 282897120 & 0.243 \\
\hline & & 116639816760 & 100 \\
\hline
\end{tabular}

Source: own elaboration based on www.gpw.pl.

Since the very beginning of its existence, the index has systematically included eight companies:

- Bank Handlowy w Warszawie S.A.,

- Grupa Azoty S.A.,

- Grupa LOTOS S.A.,

- ING Bank Śląski S.A.,

- KGHM Polska Miedź S.A.,

- Orange Polska S.A.,

- PGNiG S.A.,

- PKN Orlen S.A.

These companies are some of the largest companies in Poland. By participating in the RESPECT Index from the very beginning, these entities have had the opportunity to consistently improve their responsible business practices. This is an important fact because the experience they gained may be useful for these entities in the context of the rules that mandate the largest companies to disclose non-financial data from January 2017 [Dyrektywa Parlamentu Europejskiego...].
An in-depth analysis of the data collected for companies included in the tenth edition of the RESPECT Index indicates that $80 \%$ of them prepare non-financial reports, of which $90 \%$ are compiled according to GRI G4 standards, of which $60 \%$ are subjects of external verification [Sikacz, Wołczek 2017; Wołczek, Sikacz 2017]. The information provided allows us to assume that the vast majority of companies in the tenth edition of the RESPECT Index should deal with the obligation to disclose nonfinancial information.

The RESPECT Index pulls together companies representing such sectors as: finance (7 companies), fuel and energy (7), chemicals and raw materials (4), industrial and construction (4), consumer goods (1), protection health (1), technology (1). Taking into account the division (three sectors: industry, finance, services) the adopted survey is addressed to companies so that we will receive three groups of entities: industry (16 companies), finance ( 7 com- 
panies), services (2 companies). So we see that the current edition of the index is dominated by companies representing industry - their share is $64 \%$. The units representing the services sector account for only $8 \%$ of the composition of the index.

On the other hand, the analysis of the data presented in Table 4 indicates that the largest share in the RESPECT Index and thus the biggest influence on the value of this index are created by the following companies: KGHM Polska Miedź S.A., PZU S.A., PKN Orlen S.A., PGE S.A., BZ WBK S.A. and PGNIG S.A. The shares of the listed companies account for $58 \%$ of the portfolio of all companies making up the index.

The market value of shares of RESPECT companies is currently PLN 116.5 billion (as at August 16, 2017), of which PLN 77.8 billion (67\%) is the worth of the seven companies listed in Table 4. Among these seven companies as many as six belong to the state and the dimension of their shares totals PLN 67.2 billion, which equates to $57.6 \%$ of the portfolio value of all the RESPECT companies.

This means that the value of this index depends, to a large extent, on the price of shares of these six statecontrolled companies. These companies also have a significant impact on the value of other stock indices and their impact should be considered as significant, especially given the fact that these companies are also part of the WIG 20 index.

\section{Conclusions}

The meaningful argument in the context of the study presented above is that RESPECT companies are claiming to be socially responsible. However, it should not be unequivocally and uncritically assumed that this is the case. The doubts of the authors of the article, stressed in the passage on the selection of companies for the index, make it unclear that the companies included in this index are characterized by a high level of fulfilment and execution of CSR strategies. Stakeholders, and in particular investors potentially interested in investing in companies from this index, may experience some deficiency of information associated with the benchmark of companies for the index. There may be some doubts as to the use of the survey as a tool to evaluate companies for ESG data.

A complementary to this study will be further works by the authors of this article as a continuation of an analysis of ESG data for RESPECT companies which will be based on sample databases such as Thomson Reuters Eikon (ESG Score) and ASSET4 ESG. This analysis will in some way verify the composition of the RESPECT Index in order to meet the requirements of the environmental, social and governance factors in the index.

\section{Bibliography}

Adamczyk J., 2013, Indeksy zrównoważonego rozwoju w zarzadzaniu wartościa spółek giełdowych, Finanse, Rynki Finansowe, Ubezpieczenia, vol. 1, no. 64/2013, pp. 9-20.

Bartkowiak M., Janik B., 2013, Analiza porównawcza indeksów akcji spótek społecznie odpowiedzialnych RESPECT, CEERIUS I VONIX, Studia Oeconomica Posnaniensia, vol. 1, no. 9 (258), pp. 5-19.

Bartkowiak P., Koszel M., 2013, Indeksy giełdowe spółek społecznie odpowiedzialnych, Acta Universitatis Lodziensis. Folia Oeconomica, no. 278, pp. 161-172.

Bloomberg, 2017, Global Sustainable Investment Review 2016, http://www.gsi-alliance.org/wp-content/uploads/2017/03/ GSIR_Review2016.F.pdf (access: 10.08.2017).

Buszko M., 2013, Efektywność inwestowania na rynku kapitałowym w spółki odpowiedzialne społecznie, Prace Naukowe Uniwersytetu Ekonomicznego we Wrocławiu, no. 311, pp. 19-31.

Czerwińska T., 2012, Efektywność inwestycji społecznie odpowiedzialnych na rynku akcji, Problemy Zarządzania, vol. 10, no. 4 (39), t. 1, pp. 129-140.

Deloitte, 2016, RESPECT Index. Liderzy odpowiedzialnego biznesu, https://www2.deloitte.com/content/dam/Deloitte/ pl/Documents/Reports/Respect\%20Index/p1_Broszura_ RESPECT\%20INDEX\%20_PPT.PDF (access: 10.08.2017).

Deloitte, 2017, Wpływ czynników środowiskowych, społecznych $i$ zarządczych na sposób funkcjonowania $i$ wyceny spółek, http://www.odpowiedzialni.gpw.pl/pub/Wplyw_czynnik_ ESG_sposob_funkcjonowania_wycena_spolki.pdf (access: 10.08.2017).

Dyrektywa Parlamentu Europejskiego i Rady 2014/95/UE z dnia 22 października 2014 r. zmieniająca dyrektywę 2013/34/UE $\mathrm{w}$ odniesieniu do ujawniania informacji niefinansowych $\mathrm{i}$ informacji dotyczących różnorodności przez niektóre duże jednostki oraz grupy (Dz. Urz. UE L 330 from 15.11.2014 and Dz. Urz. UE L 207 from 04.08.2015).

Escrig-Olmedo E., Muñoz-Torres M.J., Fernández-Izquierdo M.Á., 2010, Socially responsible investing: sustainability indices, ESG rating and information provider agencies, Int. J. Sustainable Economy, vol. 2, no. 4, pp.4 42-461.

GlobeScan, SustainAbility, 2013, The 2013 Ratings Survey: Polling the Experts, http://sustainability.com/wp-content/ uploads/2016/07/ratings_research_globe_scan_sustain_ability_survey_2013.pdf (access: 10.08.2017).

Indeksy CSR na świecie, http://www.odpowiedzialni.gpw.pl/indeksy_csr_na_swiecie (access: 10.08.2017).

Jedynak T., 2012, Efektywność strategii inwestycji w akcje spótek społecznie odpowiedzialnych na przykładzie RESPECT Index, Zeszyty Naukowe Polskiego Towarzystwa Ekonomicznego, no. 12, pp. 161-172.

Krzysztofek A., 2013, Indeksy giełdowe spółek prowadzących dziatalność społecznie odpowiedzialna, Zeszyty Naukowe Wyższej Szkoły Bankowej w Poznaniu, no. 3 (48), pp. 253-264.

Krzysztofek A., 2014, Nowa formuła RESPECT Index, Prace Naukowe Uniwersytetu Ekonomicznego we Wrocławiu, no. 347 , pp. 282-291.

Lobe S., Walkshäusl C., 2011, Vice vs. virtue investing around the world, available at SSRN: https://ssrn.com/abstract=1089827 or http://dx.doi.org/10.2139/ssrn.1089827. 
Marcinkowska M., 2009, Inwestycje spotecznie odpowiedzialne, [in:] B. Filipiak, B. Mikołajczyk (eds.), Rynki finansowe w rozwoju podmiotów gospodarczych, Difin, Warszawa.

Murawski T., 2011, Społecznie odpowiedzialne inwestowanie, Miesięcznik Kapitałowy, no. 2, pp. 59-60.

Murawski T.P., 2013, Społecznie odpowiedzialne indeksy giełdowe a światowy trend rynków finansowych $w$ wymiarze ESG, Prace Naukowe Uniwersytetu Ekonomicznego we Wrocławiu, no. 311, pp. 171-181.

Opinia Europejskiego Komitetu Ekonomiczno-Społecznego w sprawie: „Wymiar etyczny i społeczny europejskich instytucji finansowych”, Dziennik Urzędowy Unii Europejskiej 2009/C 100/14, text from 30.04.2009, http://eur-lex.europa. eu/legal-content/PL/ALL/?uri=CELEX:52008IE1680 (access: 10.08.2017).

Paszkiewicz A., 2013, RESPECT Index GPW w Warszawie jako giełdowy indeks społecznej odpowiedzialności biznesu, Prace Naukowe Uniwersytetu Ekonomicznego we Wrocławiu, no. 311 , pp. $182-191$.

Sikacz H., Wołczek P., 2017, Analiza raportów informacji niefinansowych spótek z RESPECT Index, in print.
Wiśniewski T., 2010, Indeks RESPECT Index jako inicjatywa Giełdy Papierów Wartościowych $w$ procesie tworzenia zasad CSR na polskim rynku kapitałowym, Zeszyty Naukowe Szkoły Głównej Gospodarstwa Wiejskiego w Warszawie, no. 4 (53), pp. 301-311.

Wołczek P., Sikacz H., 2017, Stan raportowania informacji o stosowanej polityce różnorodności przez spótki z RESPECT Index, in print.

Wróblewska K., 2015, RESPECT Index jako bodziec do społecznie odpowiedzialnego inwestowania w Polsce, Prace Naukowe Uniwersytetu Ekonomicznego we Wrocławiu, no. 378, pp. 243-251.

www.gpw.pl.

www.odpowiedzialni.gpw.pl.

www.sustainable-investment.org.

Zasępa P., 2013, Analiza efektywności inwestycji w akcje spótek społecznie odpowiedzialnych na przyktadzie indeksu RESPECT, Prace Naukowe Uniwersytetu Ekonomicznego we Wrocławiu, no. 311, pp. 212-220.

\section{ANALIZA I FUNKCJONOWANIE INDEKSU RESPECT}

Streszczenie: Od wielu lat obserwujemy na świecie wzrost zainteresowania koncepcją społecznej odpowiedzialności biznesu (Corporate Social Responsibility - CSR). W ramach tej koncepcji rozwija się nurt odpowiedzialnego inwestowania (Socially Responsible Investing - SRI), który przejawia się m.in. powstawaniem giełdowych indeksów skupiających spółki, najwyższym stopniu spełniających wymogi dotyczące czynników środowiskowych, społecznych i ładu organizacyjnego (Environmetal, Social and Governance - ESG). Szczególni interesariusze, jakimi są inwestorzy, zwracają coraz większą uwagę na skład indeksów giełdowych opartych na spółkach odpowiedzialnych społecznie. Prezentowana praca porusza tematykę odpowiedzialnego inwestowania w Polsce, a jej głównym celem jest analiza i ocena procesu doboru spółek do indeksu RESPECT oraz przedstawienie ewolucji jaką od momentu powstania przechodzi ten indeks.

Słowa kluczowe: indeks RESPECT, indeksy CSR/SRI/ESG, odpowiedzialne inwestowanie. 